Agro-Science Journal of Tropical Agriculture, Food, Environment and Extension Volume 18 Number 2 (May 2019) pp. 15-19

ISSN 1119-7455

\title{
DETERMINANT OF FARMERS PARTICIPATION AND REPAYMENT OF OSUN RURAL ENTERPRISE AND AGRICULTURAL PROGRAM (OREAP) MICRO-CREDIT LOAN SCHEME
}

\author{
${ }^{1}$ Adebisi L.O., ${ }^{1}$ Jimoh O., ${ }^{2}$ Jonathan A., ${ }^{1}$ Osasona K.K. and ${ }^{1}$ Ojediran E.O. \\ ${ }^{1}$ Department of Agricultural Economics \& Farm Management \\ University of Ilorin, PMB 1515, Ilorin, Nigeria \\ ${ }^{2}$ Department of Agricultural Education, FCT College of Education, \\ Zuba-Abuja, Nigeria \\ *Corresponding author’s email: oluwaremilekunjimoh@yahoo.com
}

\begin{abstract}
This study examines the factors that affect farmer's participation and loan repayment of Osun Rural Enterprise and Agricultural Program (OREAP) micro credit scheme introduced by the government in Osun State. Respondents were proportionately selected from the three (3) Agricultural Development Zones in Osun State. A three-stage sampling technique was used to proportionately draw 90 beneficiaries and 90 nonbeneficiaries from the three agro-ecological zones of the state. Logit regression and ordinary least square model were used to analyze the data. The results showed that Participation in OREAP is significantly affected by gender, marital status, household size, educational status, farm size, farm income, access to extension service and membership in cooperative society. The results also revealed that education, farm income, size of loan granted, and number of loan disbursement are significantly associated with the time it took the respondents to pay back the loan. The farmer's inability to market their produce, risk and fluctuations in farm yield and uncooperative attitudes of other beneficiaries were the constraints faced by farmers as it affect their ability to repay the loan obtained through the program. The study concluded that the activities of OREAP had not been properly carried out in the study area as a result of the problems encountered by beneficiaries in obtaining and repayment of the loan. The research therefore, recommends that government and other agricultural agencies should encourage farmers to go into value additions of their produce as this will reduce gloat in the market and wastage of farm produce thereby enabling farmers to be able to repay the loan obtained for their agricultural activities.
\end{abstract}

Key words: factors, 'OREAP', credit, disbursement, default.

\section{INTRODUCTION}

In developing countries, improvement in productivity through investment in productive ventures, especially in the agricultural sector where majority of the population derive their livelihood is necessary for accelerated economic growth. At low levels of income, the accumulation of savings may be difficult. Under such circumstances, access to loans can help poor farmers to undertake investment and increase productivity. Agricultural household models suggest that farm credit is not only necessitated by the limitations of self-finance, but also by uncertainty pertaining to the level of output and the time lag between inputs and output (Kohansal and Mansoori, 2009). Facilitation of access to credit for the rural poor plays a role in alleviating rural poverty. It has been discovered that credit in small scale farmer's hand will enable him reap the economies of scale, discover new and cheaper products, create demands where none exists and provide utilities to satisfy a wider market. Furthermore, it will generate in him the optimism and determination to venture into new fields, thereby increasing farmer's livelihood (Ijere, 1998). Despite these advantages, small scale farmers have mostly been locked out of the formal financial system. This is primarily due to the lack of 'bankable' collateral, high administrative costs and perceived high risks associated with agricultural and small scale farming (Awoke, 2004). Due to the crucial role of credit especially 
in farming which is believed to be a major channel of increasing rural productivity and livelihood, Nigerian government has implemented several Agricultural Credit Programmes over the years during military as well as civilian regimes. The programmes were designed to enhance agricultural output, increase farm income, attain selfsufficiency in food production, supply adequate raw materials to industry and generate more employment and reducing rural-urban migration which no doubt should contribute to the income of rural dwellers. Tsado (2004) reported that most of the previous programmes failed to achieve the desired objectives because they were top-down in design and implementation, as most of the programmes could not further be sustained. As a result of the need for credit by small scale farmers Osun Rural Enterprise and Agricultural Programme (OREAP) a micro credit scheme which was established on the theory of 'group lending' to meet with the financial need of farmers was introduced in Osun State. OREAP was formally flagged off on $31^{\text {st }}$ March, 2011. The program which is a collaboration between Bank of Agriculture (BOA) and Osun State government has the mandate to alleviate the credit problem of farmers in the state by equipping them with soft loan through their registered cooperatives groups. This loan is given to farmers who must have form a small group of not less than 10 members and are already into agricultural production process. The credit is made available through the Bank of Agriculture, of which each farmer has access to the sum of N100, 000 minimum and N250,000 maximum. The loan is expected to be paid back within a year at an interest rate of 8 percent (Osun State ministry of Agriculture, 2012).

It has also been observed that the major reason why much success was not recorded with some of the previous schemes was as a result of high rate of loan default. In spite of the importance of loan in agricultural production, its acquisition and repayment are fraught with a number of problems especially in the small holder farming (Awoke, 2004). Osakwe and Ojo (2006) reported that large rate of default has been a perennial problem in most agricultural credit schemes organized or supported by Nigerian government. As many empirical studies have shown high default rate of micro credit loan repayment to be a major problem to the success of micro credit schemes in Nigeria hence, a study that examines the factors influencing farmer's repayment of micro credit loan is therefore important. This study examines:

- Factors affecting participation of farmers in the credit scheme;

- Factors affecting repayment of credit obtained through the scheme and;

- Constraints to the scheme.

\section{MATERIALS AND METHODS \\ Study Area}

Osun State was carved out of Oyo State on 27th

August, 1991 with Osogbo as the state capital. The state shares boundaries with Kwara state in the North, Ogun state in the south, Oyo state in the west and Ondo state in the east. The state has a landmass of about $9,251 \mathrm{~km}^{2}$. It is currently made up of 30 Local Government Areas (LGAs) spread across six main zones namely Osogbo, Ede, lwo, lkirun, llesha and lle-ife. These zones were further divided into 3 agricultural zones by Osun State Agricultural Development Project (OSSADEP) which are Osogbo, Iwo and Ife/Ijesha. The State is situated in the Western part of Nigeria and lies on latitude $8^{\circ}$ to the North and longitude $6^{\circ}$ to the South. Then it is marked by longitude $4^{\circ}$ to the west and longitude $5^{\circ}$ to the east. It exhibits the typical tropical climate with prominent wet and dry seasons with fertile soil which encourages the production of crops and livestock. The rainy season generally occur between April and October while the dry season occurs between November and March. Osun State has tropical humid climate. The mean annual temperature for Osun State varies between 21.1 and $31.1^{\circ} \mathrm{C}$. Annual rainfall is within the range of $1,000 \mathrm{~mm}$ in the derived savannah agro-ecology to $1,200 \mathrm{~mm}$ in the rainforest belt. The dominant occupation and economic activities of the people centre's around farming, agro allied productions, trading, and artisanship. The crops produced are oil palm and kernels, yams, cassava (manioc), corn (maize), pumpkins, plantain, banana and kola nuts. (OSSADEP, 2004).

\section{Data and Sampling Procedure}

The sampling frame used for beneficiaries of the program was the complete list of poultry farmers who were under the programme obtained from Osun State ministry of Agriculture comprising 1550 farmers. A two stage sampling technique was employed in selecting a total of 90 contract (Treatment group) and 90 non-contract (Control group) proportionately from Iwo, Osogbo and Ife agro-ecological zones of the state. The first stage was the purposive selection of the three agroecological zones in the state. The second stage was a proportional sampling of 180 respondents across the state.

\section{Analytical Techniques}

The data were analyzed using both descriptive and inference statistics. The descriptive statistics was used to analyze the socio-economic characteristic of rural households. The study adopts Binary logistic Regression model and ordinary least square regression model for the inference statistics. 


\section{Logistic Regression}

Estimating participation is to define an adequate measurable indicator that will distinguish between beneficiaries and non-beneficiaries. A binary variable indicating whether or not the farmer benefitted in the program.

The explanatory and dependent variables used in our econometric model are defined as follows

$$
R_{1}=E\left(y=1 / X_{i}\right)=\beta_{0}+{ }_{i} X i
$$

Where $\mathrm{X}_{\mathrm{I}}$ represents explanatory variables included in the model, $\mathrm{Y}$ - Participation in OREAP (1beneficiaries, 0-otherwise)

$\mathrm{Y}=f\left(\mathrm{X}_{1}, \mathrm{X}_{2}, \mathrm{X}_{3}, \mathrm{X}_{4}, \mathrm{X}_{5}, \mathrm{X}_{6}, \mathrm{X}_{7}, \mathrm{X}_{8, \cdots \cdots}, \mathrm{U}\right)$

$Y Y_{i}$ - OREAP (dummy Variable; $1=$ beneficiaries, 0 - otherwise)

$X \mathrm{X}_{1}$ - Marital status (dummy variable; $1=$ Single, 0 -Married)

$X \mathrm{X}_{2}$ - Farming experience (years)

$X X_{3}$ - Educational Status (years of schooling)

$\mathrm{XX}_{4}$-Gender (dummy Variable; $1=$ Male, otherwise)

$X \mathrm{X}_{5}$ - Household Size (Adult Equivalence)

$X X_{6}$ - Total farm income (Naira)

$X X_{7}-$ Membership in Cooperative society (dummy variable; 1 - member, 0 - non-member)

$X \mathrm{X}_{8}$ - Extension agent contact (dummy variable; $1=$ extension visit, 0 - otherwise)

$\mathrm{U}$ - Error term

\section{Linear regression model}

The ordinary least square (OLS) approach was used to ascertain the effect of socioeconomic variables on credit repayment ability among beneficiaries of the scheme. The use of (OLS) is informed by the fact that under normality assumption for ei, the OLS estimator is normally distributed and are said to be best, unbiased linear estimator (Gujarati, 2008).

The model one is implicitly specified as follows;

$$
\mathrm{Y}-\mathrm{f}\left(\mathrm{x}_{10}, \mathrm{x}_{11}, \mathrm{x}_{13} . \mathrm{X}+\mathrm{ei}\right) \ldots . \text { eq }
$$

The model is explicitly specified as follows;

$$
\mathrm{Y}-\alpha+\beta_{1} \mathrm{x}_{1}+\beta_{2} \mathrm{x}_{2}+\beta_{3} \mathrm{x}_{3}+\beta_{4} \mathrm{x}_{4} \quad \mathrm{~B}_{9} \mathrm{x}_{9}+\text { ei .eq }
$$

where:

$\alpha$ - intercept

$\mathrm{Y}$ - The individual's capacity to repay measured by the percentage of loan repaid. $\beta_{1}-\beta_{9}$ - Regression coefficient ei - Error term designed to capture the effects of unspecified variables in the model $\mathrm{X}_{3}$ - Educational Status (years of schooling) $\mathrm{X}_{5}$ - Household Size (adult equivalent) $\mathrm{X}_{6}$ - Total Farm income (Naira)
$\mathrm{X}_{9}$ - Age of farmer (years)

$\mathrm{X}_{10}$-Farm size (ha)

$\mathrm{X}_{11}$ - loan interest rate $(\%)$

$\mathrm{X}_{12}$ - loan size (Naira)

$\mathrm{X}_{13}$ - number of disbursement (0 - Once, 1- Twice, 2 - Instalment)

\section{RESULTS AND DISCUSSION Factors Affecting the Participation of Farmers in Oreap}

Table 1 shows the result of the factors affecting participation in the OREAP micro credit loan scheme. The results reveals that Participation in the scheme is likely to be affected by gender, marital status, household size, educational status, farm size, farm income, access to extension service and membership in cooperative society. The coefficient of marital status was significant at $10 \%$, implying that marital status of the respondents increased the likelihood of participating in OREAP. Marital responsibilities is likely to increase the need to obtain credit facilities in order to boost their output and income. Household size was also significant at $1 \%$ which implies the higher the household size, the more the likelihood of a farmer to obtain loan for his farming activities in order to improve the family livelihood. The coefficient of participation in cooperative society was significant at $1 \%$, implying that the participation of cooperative society increased the likelihood of being a beneficiary of the program. This is because participation in a farmer's cooperative society is one of the prerequisite for benefitting in the scheme. The positive and significant coefficient for cooperative group membership points at the important role played by social networks in disseminating technology information. Cooperative societies helps farmers to be well informed about various agricultural practices and programmes especially micro credit scheme that will improve their output and livelihood. The importance of social networks such as interactions with neighbors and farmer groups enhances agricultural technology dissemination, awareness and participation of agricultural programmes and innovations (Bandiera and Rasul, 2006; Matuschke and Qaim, 2009). The coefficient of educational status was positive and significant at $1 \%$ which implies that the more educated a person more the likelihood of benefitting in the scheme. This is likely to be because such a farmer is exposed to better information and can easily adopt new methods. This is in line with the result of Musigha et al. (2004) who found that education was positively related to adoption. The coefficient of access to extension service and training was significant at $1 \%$, implying that an increase in access to extension service increased the likelihood of benefiting in the scheme. 
Table 1: Logit regression result of factors affecting participation

\begin{tabular}{lll}
\hline Variables & Coefficient & $\mathrm{p}>\mathrm{Z}$ \\
\hline Household Size & 0.52609 & 0.002 \\
Gender & -1.4852 & 0.061 \\
Cooperative society & 4.516852 & 0.000 \\
Extension contact & 2.41467 & 0.000 \\
Farm Size & 0.00890 & 0.003 \\
Educational Level & 0.1799848 & 0.001 \\
Marital Status & -1.053425 & 0.081 \\
Farming Experience & -0.0159422 & 0.639 \\
Farm income & -0.005478 & 0.095 \\
Constant & 3.69681 & 0.113 \\
\hline Source: Field survey, $(2015)$. \\
Number of observation = 180; LR chi ${ }^{2}(11)=150.47 ;$ Prob> \\
chi ${ }^{2}=0.0000 ;$ Log likelihood $=-57.221213$ and Pseudo R \\
$=0.5997$
\end{tabular}

Table 2: Determinants of the loan repayment by the respondents

\begin{tabular}{lll} 
the respondents & Coefficient & t-stat \\
\hline Variable & 0.1085 & 0.10 \\
\hline Age (years) & -3.41785 & 0.256 \\
Gender (Male =1) & 0.8783 & 0.439 \\
Household size & 0.18519 & 0.485 \\
Farm Size(hectare) & 0.51097 & 0.320 \\
output(per hectares) & 0.2152944 & 0.066 \\
Years of schooling & 0.0000117 & 0.001 \\
Farm income (Naira) & 0.000042 & 0.001 \\
Loan Size(Naira) & 2.800102 & 0.424 \\
Interest on Loan & -3.338804 & 0.004 \\
Frequency of Loan & & \\
Disbursement & -15.6581 & 0.350 \\
Constant & 0.3844 & \\
$\mathrm{R}^{2}$ & 0.3009 & \\
Adjusted R &
\end{tabular}

Table 3: Distribution of beneficiaries according to constraints to the loan repayment

\begin{tabular}{lll}
\hline Rating & Frequency & Percentage \\
\hline $\begin{array}{l}\text { Constraints } \\
\text { Uncooperative attitudes of }\end{array}$ & 12 & 13.3 \\
other beneficiaries & & \\
Misappropriation of fund & 0 & 0 \\
Risk and fluctuations of yield & 28 & 31.1 \\
Marketing challenges & 50 & 55.6 \\
Total & 90 & 100 \\
\hline
\end{tabular}

This is so because majority of the beneficiaries have access to extension agents that teach them on improved farming techniques of cultivation. Similarly, extension workers provide farmers with information on the availability of new and improved technology. Empirical results elsewhere have revealed that extension contact has a significant influence on farmer adoption of new technology (Zegeye et al., 2001). Farm size was also found to be significant at $1 \%$. This shows that the larger the farm size of a farmer the likelihood the farmer has to benefit in the loan scheme. Similarly, the coefficient of farmers income from farm was negative and significant at $10 \%$, implies that farmers with lower income have demand for credit to expand their production. Hence, there is need for participating in the scheme.
Factors Affecting the Repayment of the Loan Obtained by the Respondents

Table 2 shows the result of the factors affecting farmers loan repayment of OREAP micro credit loan scheme. Table 2 reveals that adjusted $R^{2}$ was 0.3009 which implies that the variables in the model were able to explain 30 percent of the variability in percentage of loan repayment. This $\mathrm{R}^{2}$ was high compared to 0.20 reported by Oni (1999) for loan repayment among the smallholder clients of Nigerian Agricultural and Co-operative Bank and the Union Bank of Nigeria in Osun State. The results also reveals that year of schooling, farm income, size of loan granted, and frequency of loan disbursement are significantly associated with their capacity to repay the loan. The coefficient of years spent in school was positive and significant at $10 \%$ which implies that more educated farmers have high capacity to repay the loan. Also the coefficient of farm income of the respondents was positive and significant at $1 \%$ which implies that the higher the beneficiaries' farm income, the better their capacity to repay the loan. The coefficient of loan size was positive and significant at $1 \%$ which implies that the larger the loan disbursed to the farmers, the better their ability to repay the loan back. This may be because large capital is needed for their farming activities. This agrees with Dadson (2012) who established that loan volume disbursed was a significant determinant of loan repayment among smallholder farmers. Also, the coefficient of frequency of loan disbursement is negative and significant at $1 \%$ which implies that if the money is disbursed at once farmers are able to make good use of the money for their farming activities at the right time and so they will be able to repay to time. Distribution of beneficiaries according to constraints to the repayment of loan acquired Table 3 shows that the farmers inability to market their farm produce after obtaining the loan, which is as a result of gloat that occurred in the market that brought down the price of this commodities thereby making it difficult for farmers to repay the loan obtained for their planting activities. Also farmers encountered several risks and fluctuations in farm yield which affected their repayment abilities. The uncooperative attitudes of the farmers affected their ability to repay the loan obtained through the program. This is reflected in their inability to synergize effort in production which will consequently be useful in overcoming challenges encountered in their production and marketing activities.

\section{CONCLUSION AND RECOMMENDATIONS}

The findings indicated that the activities of OREAP had not been properly carried out in the study area as a result of the problems encountered by beneficiaries in obtaining and repayment of the 
loan. Moreover, if these problems are properly addressed by the authorities concerned, the desired objectives of the scheme would be realized. It is also recommended that government and other agricultural agencies should encourage farmers to go into value additions of their produce as this will reduce gloat in the market and wastage of farm produce thereby enabling farmers to be able to repay the loan obtained for their agricultural activities. Farmers should also be educated on prudent use of microcredit loan scheme as this will enhance the repayment of loan obtained. There should be proper monitoring of farmers use of such credit by agricultural extension agents through their cooperatives groups. This will ensure proper use of the fund borrowed and reduce loan default rate.

\section{REFERENCES}

Awoke M.U. (2004). Factors Affecting Loan Acquisition and Repayment Patterns of Smallholder Farmers in Ika North-East of Delta State, Nigeria. Journal of Sustainable Tropical Agricultural Research, 9, 61- 64.

Bamiro O.M. (2007). Economics of Vertical Integration in the Poultry Industry in South-West, Nigeria. Unpublished Ph.D. Thesis, Department of Agricultural Economics and Farm Management, University of Agriculture, Abeokuta, Nigeria.

Bandiera O. and Rasul I. (2006). Social networks and technology adoption in northern Mozambique. The Economic Journal 116, 869-902.

Dadson A.V. (2012). Determinants of Loan Repayment Default among Farmers in Ghana. J. Develop. Agric. Econ. 4 (13), 339-345.

Gujarati, D. N. (2008). Basic econometrics. New York, NY: McGraw-Hill.
Ijere M.O. (1998). Agricultural Credit and Economic Development. European Journal of Social Science Readings in Agricultural finance, 7(2). Eurojournals, Inc. Engl

Kohansal M.R. and Mansoori H. (2009). Factors Affecting on loan Repayment Performance of Farmers in Khorasan-Razavi Province of Iran: Paper presented at Conference on International Research on Food Security, Natural Resource Management and Rural Development Tropentag 2009, University of Hamburg, October pp. 6-8.

Matuschke I. and Qaim M. (2009). The impact of social networks on hybrid seed adoption in India. Agricultural Economics 40, 493-505.

Osakwe, J.O. and Ojo M.O. (2006). An Appraisal of Public Sector Financing of Agricultural Development in Africa with Particular Reference to Nigeria. CBN Economic and Financial Review, 24 (2), 33- 41.

OSSADEP (2004). Osun State Agriculture Development Programme. Annual Report on Fadama Programme. Iwo, Osun State.

Osun State Ministry of Agriculture (2012). "Booting Agricultural Activities in Osun State" Retrieved from http://www.osundefender.org/

Tsado J.H. (2004). Women's involvement in farming Activities and Household food security in Dako Local Government Area of Niger State Msc. Thesis submitted to Faculty of Agriculture, University of Ilorin, Nigeria.

Zegeye T., Tadesse B. and Tesfaye S. (2001). Determinants of adoption of improved maize technologies in major maize growing regions in Ethiopia. Second National Maize Workshop of Ethiopia, 12-16 November, Addis Ababa, Ethiopia.

Zeller S., Ahmed and Rashid. (2001). Group-based Financial Institutions for the Rural Poor in Bangladeshi: An Institutional and Household Level Analysis. Research Report 120, IFPRI, Washington, D.C. 